African Crop Science Journal by African Crop Science Society is licensed under a Creative Commons Attribution 3.0 Uganda License. Based on a work at www.ajol.info/ and www.bioline.org.br/cs DOI: http://dx.doi.org/10.4314/acsj.v25i1.7

\title{
COMBINING ABILITY AND GENETIC ANALYSIS OF FRUIT AND LEAF YIELD IN GBOMA EGGPLANT
}

\section{NYADANU ${ }^{1,4}$, R. ADU AMOAH ${ }^{1}$, A.O. KWARTENG ${ }^{1}$, R. AKROMAH ${ }^{1}$, L.M. ABOAGYE ${ }^{2}$, H. ADU-DAPAAH ${ }^{3}$, F.K. DAGADU ${ }^{4}$, D. KYIRIKA ${ }^{4}$, K.G. JOTI ${ }^{4}$ and G. OPPONG ${ }^{4}$}

${ }^{1}$ Department of Crop and Soil Sciences, Kwame Nkrumah University of Science and Technology, Private Mail Bag, University Post Office, Kumasi, Ghana

${ }^{2}$ Plant Genetic Resources Research Institute, CSIR, P. O. Box 7, Bunso, Eastern Region, Ghana

${ }^{3}$ Crops Research Institute, CSIR, Ghana, P. O. Box 3785, Fumesua-Kumasi, Ghana

${ }^{4}$ Department of Crop and Soil Science Education, College of Agriculture Education, University of Education, Winneba, P. O. Box 40 Asante-Mampong, Kumasi, Ghana

Corresponding author: dnyadanu@gmail.com

(Received 18 October, 2016; accepted 22 February, 2017)

\begin{abstract}
Gboma eggplant (Solanum macrocapon L.) of the family Solanaceae is an important fruit and leafy indigenous vegetable in Africa. Despite the numerous nutritional, medicinal and economic benefits derived from the crop, little is known about the genetic parameters governing the inheritance and combining ability of the yield components. Thus, a study was conducted to investigate genetic information on the relevant yield components of the crop. Results showed significant mean squares for General Combining Ability, Specific Combining Ability effects for number of leaves per plant, fruit width and plant height, indicating the combining effect of additive, non-additive and maternal effects for expression for those traits. Conversely, significant $(\mathrm{P}<0.05)$ SCA effects for number of branches per plant, leaf length, leaf width and fresh leaf weight indicated the preponderance of non-additive gene effect. GCA/SCA ratios for the various traits indicated that the relative contribution of additive to non-additive effects varied widely from trait to trait. Significant reciprocal effects for most of the traits were an indication that cytoplasmic or maternal gene effects played a major role in modifying the inheritance of the yield parameters, and that the choice of the maternal parent is relevant in breeding for these traits. Estimated GCA effect among the parents revealed that CAGRIC 03 has a breeding value for number of branches, plant height, fruit length, leaf length and fresh leaf weight, which makes it a valuable material for development of improved varieties. CAGRIC 01 was the promising combiner to increase fruit weight and number of leaves per plant. Hybrid P1xP2 was the best specific combiner to increase fruit width, leaf width and fruit width. High heritability estimates for most of the traits indicate that genetic variation was higher than the environmental variation in the study.
\end{abstract}

Key Words: African eggplant, heritability, Solanum macrocapon

\section{RÉSUMÉ}

Aubergine gboma (Solanum macrocapon L.) de la famille des solanacéesest un fruit important et légumes indigènes feuillues en Afrique. Malgré de nombreux avantages nutritionnels, médicinaux et économiques découlant de la culture, peu est connu sur les paramètres génétiques régissant l'héritage et la capacité de combinaison des composants de rendement. Ainsi, une étude était initiée pour générer del'information génétique sur d'importants composants de rendementde la culture. Les résultats ont montré des carrés moyens significatifs pour à l'aptitude generale de combinaison, les effets de la capacité spécifique de combinaison pour le nombre de feuilles par plante, la largeur des fruits et la hauteur de plant, ce qui témoign edes effets additifs et non additif et maternels combinés 
pour l'expression de ces traits. Inversement, les effets significatifs $(\mathrm{P}<0,05)$ de CCSsur le nombre de branches par plant, la longueuret la largeur des feuilles ainsi que le poids de feuilles fraîches indiquent la prépondérance de l'effet du gène non-additif. Les rapports GCA/SCA pour les différents traits indiquent que la contribution relative de l'additif aux effets non additifs variait largement d'un trait à l'autre. Des effets réciproques significatifs pour la plupart des traits indiqueque les effets génétiques cytoplasmique sou maternels ont joué un rôle majeur dans la modification de l'héritage des paramètres de rendement et que le choix du parent maternel est pertinent dans l'amélioration de ces traits. L'effetestimé deGCA chez les parents a révélé que CAGRIC 03 est d' une valeur ameliorative pour le nombre de branches, la hauteur de la plante, la longueur des fruits, la longueur des feuilles et le poids des feuilles fraîches, ce qui en fait un matériel précieux pour le développement de variétés améliorées. CAGRIC 01 était le combinateur prometteur pour augmenter le poids de fruits et le nombre de feuilles par plant. L'hybride P1xP2 était le meilleur combineur spécifique pour augmenter la largeur du fruit, la largeur des feuilles et la largeur du fruit. Des valeurs élevées d'héritabilité pour la plupart des traits indiquent que la variation génétique était plus élevée que la variation environnementale dans l'étude.

Mots Clés: Aubergine africaine, hérédité, Solanum macrocarpon

\section{INTRODUCTION}

Solanum macrocarpon L., of the family Solanaceae, is an important food crop in West and Central Africa, and is mostly referred to as African eggplant or Gboma. It is a tropical perennial plant that is related to the eggplant (Oboh et al., 2005), found throughout the warmer and non-arid parts of Africa, where it is an important fruit or leafy vegetable (Schippers, 2000). It is an inexpensive food, thus a major food component of human diet in most developing homes in the world over. It is rich in protein, fiber, calcium, iron, potassium, magnesium, phosphorus and sodium (Agoreyo et al., 2012; Nyadanu and Lowor, 2015).

Apart from being considered as an important vegetable crop, it is exploited for medicinal purposes. Some indigenous medicinal uses include treatment of conditions such as asthma, allergic rhinitis, nasal catarrh, skin infections, rheumatic diseases and joint pains swollen reflux disease gastroesophageal, constipation, and dyspepsia (Nwodo et al., 2011). It also has the ability to provide precursors for the synthesis of useful drugs, apart from its nutritional and therapeutic qualities.

In spite of the nutritional, medicinal and economic importance of the crop, there is paucity of information about the inheritance of yield and yield components of the crop. The inadequacy of progress in breeding for highyielding varieties for the crop is partly due to insufficient knowledge of the nature of the genetic control, heritability and combining ability of parents for yield and its related traits. Yield is considered to be a complex character controlled by the actions of other related traits (Chandra et al., 1990: Rao et al., 1990).

The concept of combining ability analysis helps to estimate the nature and magnitude of the gene actions involved in the inheritance of the quantitative traits. The aim of this research was, therefore, to determine the gene action governing the inheritance of yield components and combining ability in nine Gboma cultivars to provide appropriate information that could be useful in Gboma improvement programmes aimed at improving fruit and leaf yield.

\section{MATERIALS AND METHODS}

Location of experiment. The experiment was carried out at the Multipurpose Crop Nursery at the College of Agriculture of the University of Education, Winneba, Mampong Campus, Kumasi, Ghana. The area is located on latitude 07 and 03 North and longitude 01 and $24 \mathrm{~W}$; and at $457.5 \mathrm{~m}$ above sea level. It is within the transitional zone, which occurs between the Guinea savannah in the north and the rainforest region in the south (Meteorological Department, Mampong, Ashanti, 2007). 
Plant material. A set of 9x9 full diallel crosses of Gboma were produced using varieties CAGRIC 01(P1), CAGRIC 02(P2), CAGRIC 03(P3), CAGRIC 04(P4), CAGRIC 05(P5), CAGRIC 06(P6), CAGRIC 07(P7), CAGRIC 08(P8) and CAGRIC 09(P9). They are accessions of the local landraces of Gboma eggplant collected from Volta, Ashanti, Eastern, Brong-Ahafo, Western and Northern regions of Ghana. Extracted Seeds of the 81 genotypes (36 direct F1s crosses, 36 reciprocal crosses and 9 selfed) were first nursed at the nursery. Seedlings of the various genotypes at four leaf stage were transplanted to a $3 \mathrm{~m} \times 2 \mathrm{~m}$ bed, in a randomised complete block design, with three replication, and at a spacing of $50 \mathrm{~cm} \mathrm{x}$ $50 \mathrm{~cm}$ and a path of $1 \mathrm{~m}$ was left between plots and blocks.

There were three rows of plants per-plot for each plant. Appropriate cultural practices such as weed control, pest and disease control, irrigation and mulching were adopted to maintain healthy growth of the plants. The commonest weed on the experimental field was Cyperus spp. The weed was controlled by hand-pulling and hoeing. Data on the following traits were recorded on 6 randomly selected plants:

Number of leaves per plant (NLPP). Number of leaves per plant for the six plants per plot was determined by counting and the average value for each plot recorded.

Leaf length (LL). The five leaves for each leaf blade per plant for the six plants per plot was determined by measuring with a metre from the base of the leaf to the tip of the leaf blade and the average for each plot was calculated as the average for the six plants.

Plant height (PH). Six plants per plot measured with metre rule from the soil level to the tip of the apical bud. The average value for each plot was calculated as the average for the six plants.
Fruit length (FL). Length of five fruits per plant for six plants per plot was determined using the vernier calliper. The measurements were taken from the apex of the fruit to the base of the calyx and the average for each plot was calculated as the average for the six plants.

Branches per plant (NBPP). The number of branches per stem for the six plants per plot was determined by counting and the average for each plot was calculated as the average for the six plants.

Fresh fruit weight (FFW). Fresh fruit weights of the fifteen varieties of gboma used was weighted in kilogrammes $(\mathrm{kg})$ with a weighing balance and converted to grammes (g).

Leaf width (LW). The width of five leaf blades per plant, for the six plants per plot, was determined by measuring at the widest point of the leaf blade with a metre rule and the average for each plot was calculated as the average for the six plants.

Fresh leaves weight (FLW). Fresh leaves fruits weight of the fifteen varieties of gboma used was weighed in kilogrammes $(\mathrm{kg})$ with a weighing balance and converted to grammes (g) and recorded.

Data analysis. Analysis of variance and diallel analysis according to the Griffing (1956) method 1, fixed model were carried out using the PBTools, Version 1.4. 2014.

$Y i j=\mu+g_{i}+g_{j}+s_{i j}+r_{i j}+\frac{1}{b c} \sum_{k} \sum_{l} \varepsilon_{i j k l}$

Where $U=$ the population mean, $g_{i}, g_{j}=$ the general combining ability effect for the $i^{\text {th }}$ and $j^{\text {th }}$ parents, $s_{i j}=$ the specific combining ability effect of the cross between the $i^{\text {th }}$ and $\mathrm{j}^{\text {th }}$ parents such that $s_{i j}=s_{j i}, r_{i j}=$ the reciprocal effect involving the reciprocal crosses between 
the $i^{\text {th }}$ and $j^{\text {th }}$ parents such that $r_{i j}=r_{j i}$ and, $e_{i j k l}=$ the experimental error due to environmental effect associated with the $i j k l^{\text {th }}$, which is assumed to be uncorrelated and normally distributed with zero mean and variance, $V_{E^{*}}$

Genetic gain was determined using the formula as described by Falconer (1989): $\Delta \mathrm{G}$ $=\mathrm{ih}^{2} \delta \mathrm{p}$.

Where:

$\Delta \mathrm{G}=$ genetic gain or genetic advance,

$\mathrm{i}=$ intensity of selection,

$\mathrm{h}^{2}=$ heritability, and

$\delta \mathrm{p}=$ phenotypic standard deviation of the parental population

The average degree of dominance was estimated according to (Singh and Chaudhary, 1979): viz $\sqrt{ } \mathrm{H} / \mathrm{D}=\checkmark\left(\delta^{2} \mathrm{gca} / \delta^{2}\right.$ sca $)$.

The additive $\left(\delta^{2} \mathrm{~A}\right)$, non-additive $\left(\delta{ }^{2} \mathrm{NA}\right)$, and environmental $\left(\delta^{2} \mathrm{SE}\right)$ variance were computed according to Nyadanu et al. (2012); using mean squares for GCA (MSg), SCA (MSs), and error (MSE) extracted from the analysis of variance table as follows:

$\delta^{2} 2 \mathrm{~A}=(\mathrm{MSg}-\mathrm{MSs}) /(\mathrm{P}+2) ;$

$\delta^{2} \mathrm{NA}=\mathrm{MSs}-\mathrm{MSE}$;

$\delta^{2} 2 \mathrm{E}=\mathrm{MSE}$;

$\mathrm{P}=$ number of parents.
Broad sense heritability $\left(\mathrm{H}^{2}\right)$ was computed as follows: $\mathrm{H}^{2}=\left(\delta^{2} \mathrm{~A}+\delta^{2} 2 \mathrm{NA}\right) /\left(\delta^{2} \mathrm{~A}+\delta^{2} 2 \mathrm{NA}\right.$ $\left.+\delta^{2} \mathrm{E}\right)$.

The heritability percentage was categorised as low, moderate and high, similar to that of Robinson et al. (1949) as $<50 \%=10 w, 50 \%=$ moderate and $>50 \%=$ high .

\section{RESULTS}

Combining ability effects. Table 1 shows the analysis of variance of the mean squares due to the GCA, SCA, reciprocal effect and the GCA/SCA ratios for all the characters. GCA was significant $(\mathrm{P}<0.05)$ for number of leaves per plant (LPP), fresh fruit weight (FFW), plant height (PH) and fruit Length (FL), GCA (Table 1). Conversely, number of branches per plant (NBPP), leaf length (LL), leaf width (LW) and fresh leaf weight (FLW) showed a nonsignificant $(\mathrm{P}>0.05)$ GCA effect. Mean square due to SCA was significant $(\mathrm{P}<0.05)$ for LLP, LL, PH, LW, NB, FW and FLW.

Fruit length was the only parameter that had a non-significant SCA (Table 1). Mean square due to reciprocal effects were significant for all the traits studied. Significant reciprocal effects were recorded for all the traits studied, except number of branches per plant. The GCA and SCA ratios ranged from $0.6851-3.7404$. Number of branches per plant recorded the lowest GCA and SCA ratios;

TABLE 1. Analysis of variance for combining ability effects of different Gboma traits

\begin{tabular}{lccllllll}
\hline Source of variation & \multicolumn{8}{c}{ Msq } \\
\cline { 2 - 9 } & NLPP & NB & LL & PH & FL & LW & FFW & FLW \\
\hline GCA & $1335.11^{*}$ & 5.96 & 3.07 & $131.14^{* *}$ & $0.53^{*}$ & 1.71 & $0.7219^{*}$ & 0.0093 \\
SCA & $577.51^{* * *}$ & $8.7^{*}$ & $3.82^{* * *}$ & $35.06^{* * *}$ & 0.23 & $1.63^{* * *}$ & $0.3408^{*}$ & $0.0064^{*}$ \\
Reciprocals & $455.53^{* * *}$ & 4.73 & $5.07^{* * *}$ & $61.82^{* * *}$ & $0.42^{* *}$ & $2.79^{* * *}$ & $0.4466^{* *}$ & $0.0056^{*}$ \\
Error & 88.82 & 3.19 & 1.42 & 13.10 & 0.19 & 0.54 & 0.2259 & 0.0037 \\
GCA/SCA & 2.31 & 0.69 & 0.80 & 3.74 & 2.30 & 1.05 & 2.12 & 1.45 \\
\hline
\end{tabular}

NLLPP $=$ Number of leaves per plant, $\mathrm{NB}=$ Number of branches per plant, $\mathrm{LL}=$ Leaf length, $\mathrm{PH}=\mathrm{Plant}$ height, $\mathrm{FL}=$ Fruit length, $\mathrm{LW}=$ Leaf width, FFW $=$ Fresh fruit weight, FLW $=$ Fresh leaf weight. GCA = General combining ability, $\mathrm{SCA}=$ Specific combining ability, ${ }^{*}=$ data significant at $\mathrm{P}<0.05$, $* *=$ data significant at $\mathrm{P}<$ $0.01, * * *=$ data significant at $\mathrm{P}<0.001$ 
whereas $\mathrm{PH}$ recorded the highest GCA and SCA ratios. NBPP and LL recorded higher ratios of 0.6851 and 0.8037 , respectively (Table 1).

General combining ability. P3 recorded the highest positive GCA effect for NBPP, LL, PH, FL and FLW, respectively $(0.71,0.57,2.97$, 0.26 and 0.02 ) (Table 2). Whereas P1 recorded the highest GCA effect for number of leaf per plant and fruit width, with a positive GCA values of 10.72 and 0.21 , respectively. On the contrary P8 recorded the lowest GCA effect for LPP, LW, NBPP with GCA effect of -17.94, -0.51 , and -1.08 , respectively. $\mathrm{P} 9$ had the lowest GCA effect for LL and PH, whereas P6 had the lowest GCA effect for FLW and FFW of -0.03 and -0.26 , respectively (Table 2).

Specific combining ability. SCA effect for both direct and reciprocal crosses are presented in Table 3. Results for NLP indicated that the direct and reciprocal crosses had 15 and 23 positive SCA, respectively. Hybrid P4 $x$ P5 recorded the highest positive SCA effect of 35.53 in the direct cross; while P6 xP8 obtained the highest in the reciprocal manner with SCA of 30.44. The lowest positive SCA effects of 0.14 and 0.00 were recorded by hybrid $\mathrm{P} 3 \mathrm{xP} 5$ and $\mathrm{P} 4 \mathrm{xP} 8$ in the direct and reciprocal crosses accordingly. Out of the 21 and 13 negative SCA effects obtained by the direct and reciprocal crosses, cross $\mathrm{P} 3 \times \mathrm{P} 5$ and hybrid P1xP9 gave the highest negative SCA -35.32 and -27.22 , respectively (Table 3).

With regards to number of branches (NB), both the direct and reciprocal crosses produced 18 positive and 18 negative SCA effects in the possible 36 crosses. Surprisingly, P1xP3 provided the highest positive SCA effect of 6.77 and 5.89 in the direct and reciprocal cross, respectively (Table 3). Also, while hybrid $\mathrm{P} 3 \mathrm{xP} 4$ gave the highest negative SCA $(-3.6)$ in the direct cross, it recorded the lowest positive SCA (0.09) in the reciprocal cross. Hybrids P7xP8 and P5xP7 obtained the lowest positive and highest negative SCA effect in the direct and reciprocal crosses, respectively.

For LL, direct and reciprocal crosses produced 17, 26 positive and 19, 10 negative SCA, respectively. Cross $\mathrm{P} 1 \times \mathrm{PP} 8$ recorded the highest positive SCA (2.12) and cross $\mathrm{P} 2 \times \mathrm{P} 4$ the highest negative SCA (-1.79) in the direct cross. Likewise, hybrid $\mathrm{P} 2 \mathrm{xP} 9$ gave the highest positive $\mathrm{SCA}(3.44)$ and hybrid $\mathrm{P} 2 \mathrm{xP} 4$ recorded the least positive SCA effect of 0.15 in the reciprocal crosses. Hybrid P7xP9 recorded the

TABLE 2. General combining ability effects for characters in Gboma parents

\begin{tabular}{lrrrrrrrr}
\hline \multirow{2}{*}{ Parents } & \multicolumn{7}{c}{ Traits } \\
\cline { 2 - 9 } & NLPP & \multicolumn{1}{c}{ NBPP } & \multicolumn{1}{c}{ LL } & \multicolumn{1}{c}{ PH } & \multicolumn{1}{c}{ FL } & LW & FLW & FW \\
\hline CAGRIC 01(P1) & 10.72 & 0.42 & 0.12 & 2.71 & 0.11 & 0.08 & 0.01 & 0.21 \\
CAGRIC 02(P2) & 7.23 & 0.30 & -0.40 & 2.83 & -0.15 & 0.42 & 0.01 & 0.16 \\
CAGRIC 03(P3) & 1.59 & 0.71 & 0.57 & 2.97 & 0.26 & -0.16 & 0.02 & 0.16 \\
CAGRIC 01(P4) & -1.35 & 0.18 & 0.15 & 0.20 & -0.08 & 0.44 & -0.02 & -0.16 \\
CAGRIC 01(P5) & 3.55 & 0.04 & -0.45 & 1.30 & -0.15 & -0.14 & -0.03 & -0.25 \\
CAGRIC 01(P6) & 5.01 & -0.78 & -0.22 & -2.78 & 0.05 & -0.19 & -0.03 & -0.26 \\
CAGRIC 01(P7) & -0.98 & -0.08 & 0.52 & -0.36 & 0.10 & 0.17 & 0.01 & 0.18 \\
CAGRIC 01(P8) & -17.94 & -1.08 & 0.24 & -2.73 & 0.13 & -0.51 & 0.02 & 0.11 \\
CAGRIC 01(P9) & -7.83 & 0.28 & -0.52 & -4.14 & -0.27 & -0.11 & 0.01 & -0.16 \\
\hline
\end{tabular}

NLLPP $=$ Number of leaves per plant, NBPP $=$ Number of branches per plant, $L L=$ Leaf length, $\mathrm{PH}=\mathrm{Plant}$ height, FL = Fruit length, LW = Leaf width, FFW = Fresh fruit width, FLW = Fresh leaf weight 
TABLE 3. Specific and reciprocal combining ability of the various yield components of Gboma in Ghana

Cross

Traits

$\begin{array}{lllllllll}\text { NLPP } & \text { NB } & \text { LL } & \text { PH } & \text { FL } & \text { LW } & \text { FFW } & \text { FLW }\end{array}$

Direct Reciprocal Direct Reciprocal Direct Reciprocal Direct Reciprocal Direct Reciprocal Direct Reciprocal Direct Reciprocal Direct Reciprocal

\begin{tabular}{|c|c|c|c|c|c|c|c|c|c|c|c|c|c|c|c|c|}
\hline P1XP2 & -5.30 & 25.67 & -1.68 & 0.69 & -0.76 & 0.50 & -3.38 & 6.81 & 0.01 & 0.17 & -0.88 & 1.50 & 0.24 & 0.170 & 0.030 & 0.020 \\
\hline P1XP3 & 30.17 & -0.22 & 6.77 & 5.89 & -0.26 & 0.37 & 4.32 & -0.98 & -0.50 & 0.21 & 1.31 & -0.07 & -0.9 & -0.010 & -0.090 & -0.003 \\
\hline P1XP4 & -1.14 & 26.58 & 0.77 & 0.42 & 0.28 & 0.15 & 3.19 & 7.08 & 0.13 & 0.13 & -0.01 & 0.78 & 0.22 & -0.180 & 0.031 & -0.010 \\
\hline P1XP5 & -26.95 & -0.33 & -0.79 & -1.66 & 0.50 & 1.71 & 2.82 & 8.48 & -0.25 & 0.02 & -0.21 & -0.33 & 0.82 & 0.333 & 0.080 & 0.020 \\
\hline P1XP6 & 10.56 & -3.92 & 0.10 & 0.15 & -0.65 & 0.57 & 0.67 & -1.58 & -0.25 & -0.07 & -0.75 & 1.08 & -0.7 & -0.200 & -0.060 & -0.020 \\
\hline P1XP7 & -6.48 & 4.17 & -0.50 & 0.60 & 1.78 & 0.56 & -0.66 & 11.67 & 0.05 & -0.10 & 0.92 & 1.44 & -0.15 & 0.470 & 0.000 & 0.040 \\
\hline P1XP8 & -3.79 & 10.67 & -2.50 & -0.04 & 2.12 & -1.32 & 1.87 & 2.83 & 0.46 & 1.00 & -0.83 & 0.00 & 0.62 & 0.170 & 0.050 & 0.010 \\
\hline P1XP9 & 8.82 & -27.22 & -0.86 & -1.78 & -1.53 & -2.74 & -4.44 & -13.72 & 0.15 & -0.44 & 0.05 & -0.97 & -0.6 & -0.450 & -0.030 & -0.050 \\
\hline P2XP3 & 17.39 & 0.56 & 0.17 & 1.44 & -0.56 & 1.72 & 6.48 & -4.42 & -0.16 & 0.26 & 0.26 & 1.92 & 0.89 & -1.230 & 0.060 & -0.090 \\
\hline P2XP4 & 11.16 & 3.39 & 0.07 & 0.40 & -1.79 & -0.51 & -7.81 & 1.53 & -0.07 & 0.00 & -0.74 & 0.05 & -0.5 & 0.050 & -0.040 & 0.010 \\
\hline P2XP5 & 5.37 & -21.50 & 1.14 & 1.00 & -0.61 & 1.60 & 2.59 & 5.97 & 0.31 & 0.35 & 0.44 & 0.01 & 0.07 & 0.800 & 0.020 & 0.080 \\
\hline P2XP6 & -17.76 & 10.50 & -0.27 & -0.70 & -0.51 & -0.64 & -7.36 & 2.67 & -0.12 & 0.08 & 0.00 & 0.83 & -0.13 & 0.000 & 0.000 & 0.000 \\
\hline P2XP7 & 6.95 & 18.22 & -0.83 & 0.66 & 1.70 & 0.62 & -0.83 & 13.61 & -0.01 & 0.58 & 0.85 & 0.71 & 0.29 & 0.860 & 0.030 & 0.070 \\
\hline P2XP8 & -18.47 & 7.50 & -2.79 & -0.30 & -1.66 & 1.89 & 8.59 & 0.67 & 0.06 & 0.33 & 1.00 & 2.83 & -0.5 & -0.330 & -0.050 & -0.040 \\
\hline P2XP9 & 0.14 & -2.22 & 2.02 & 0.10 & 0.59 & 3.44 & -0.31 & 3.97 & 0.31 & 0.47 & 1.50 & 3.25 & 0.19 & 1.250 & -0.020 & 0.120 \\
\hline P3XP4 & -8.59 & -1.67 & -3.60 & 0.09 & 2.08 & 1.00 & -6.48 & -5.00 & 0.51 & 0.67 & -1.05 & 0.83 & 0.11 & 0.670 & 0.000 & 0.070 \\
\hline P3XP5 & -35.32 & 7.50 & -0.05 & 0.72 & -0.82 & -0.17 & -2.58 & -2.30 & -0.08 & 0.33 & -1.64 & -1.00 & -0.63 & 0.500 & -0.070 & 0.060 \\
\hline P3XP6 & -4.28 & -18.67 & -2.03 & -0.21 & 1.71 & 0.40 & -1.17 & 5.00 & -0.12 & -0.17 & -0.42 & -0.50 & 0.21 & 0.000 & 0.000 & -0.008 \\
\hline P3XP7 & -5.29 & -3.00 & 1.76 & -0.73 & 0.18 & -0.56 & -0.58 & -0.67 & 0.33 & 1.00 & 0.05 & -0.33 & -0.11 & -0.220 & -0.010 & -0.020 \\
\hline P3XP8 & 16.90 & 9.56 & 0.59 & -0.50 & 0.75 & 1.80 & 5.73 & 9.28 & 0.35 & 0.04 & 2.02 & 2.28 & 0.16 & 0.320 & 0.150 & 0.190 \\
\hline Р3XP9 & -2.02 & 22.42 & -1.36 & -0.07 & -0.55 & 0.70 & 0.47 & 4.77 & -0.50 & 0.46 & 0.41 & 1.40 & -0.19 & 0.040 & -0.060 & 0.003 \\
\hline P4XP5 & 35.53 & 18.69 & 1.51 & 0.40 & -0.45 & 0.89 & 0.27 & 1.86 & 0.35 & 0.41 & 1.00 & 1.22 & -0.09 & 0.570 & 0.000 & 0.060 \\
\hline P4XP6 & -26.66 & 12.98 & -2.70 & -0.03 & 0.37 & 1.50 & 0.23 & 0.50 & -0.28 & -0.33 & -0.52 & 0.00 & 0.37 & -0.170 & 0.050 & -0.020 \\
\hline P4XP7 & 6.14 & 5.50 & -0.49 & -1.45 & -0.08 & 1.82 & 4.43 & -0.67 & 0.33 & 0.66 & 0.93 & 1.47 & 0.07 & 0.310 & 0.000 & 0.020 \\
\hline P4XP8 & -16.06 & 0.00 & 2.40 & -0.21 & -1.24 & 1.22 & 0.38 & 9.28 & -0.35 & -0.67 & -0.36 & 1.17 & 0 & 0.170 & 0.000 & 0.020 \\
\hline P4XP9 & -34.50 & 1.33 & 2.28 & -0.36 & 1.83 & -0.33 & 6.63 & 4.77 & -0.47 & 0.15 & 0.24 & -0.50 & 0.26 & 0.170 & 0.000 & 0.020 \\
\hline P5XP6 & 14.71 & 14.62 & 1.72 & 1.04 & 0.63 & 0.95 & 2.97 & 4.31 & -0.23 & 0.26 & 1.15 & 0.28 & 0.16 & 0.540 & 0.020 & 0.060 \\
\hline P5XP7 & 13.05 & -5.97 & 0.08 & -2.69 & 1.21 & 0.19 & -1.56 & -7.69 & 0.13 & -0.39 & -0.37 & -1.27 & -0.04 & -0.450 & 0.004 & -0.040 \\
\hline P5XP8 & -11.79 & 11.50 & -0.48 & 0.30 & -0.27 & 2.34 & -3.89 & -1.67 & -0.28 & -1.00 & -0.45 & 0.17 & 0.25 & 0.000 & 0.020 & -0.003 \\
\hline
\end{tabular}


highest negative SCA (-4.0) in the reciprocal crosses category whereas hybrid P3xP5 recorded the least $-\mathrm{SCA}(-0.17)$ (Table 3).

For $\mathrm{PH}$, the direct cross produced 21 positive and 15 negative SCA; while the reciprocal recorded 23 positive and 13 negative SCA. Cross $\mathrm{P} 2 \mathrm{xP} 8$ gave the highest positive SCA of 8.59 in the direct cross; while cross P2xP7 with SCA of 13.61 gave the highest positive SCA in the reciprocal cross. Cross P3xP7 obtained the lowest negative SCA $(-0.67)$ in the reciprocal cross. Cross P4xP6 and cross $\mathrm{P} 7$ and $\mathrm{P} 9$, respectively, obtained the lowest positive SCA in the direct and reciprocal cross of 0.23 and 0.33 , respectively.

For FL, the direct cross produced equal number of positive and negative SCA of 18 out of the 36. Hybrid P6xP8 gave the highest positive SCA of 0.52 in the direct cross; while the same cross conjointly with P5xP8 obtained the highest negative SCA (-1.0) in the reciprocal cross. Hybrid $\mathrm{P} 2 \mathrm{xP} 4$ and $\mathrm{P} 7 \mathrm{xP} 8$ produced the lowest positive SCA (0.00) in the reciprocal hybrid $\mathrm{p} 1 \mathrm{xp} 3$ and $\mathrm{p} 3 \mathrm{xp} 9$ gave the highest negative SCA of -0.5 in the direct cross. Hybrid p1xp8 and p3xp7 also shared status as the highest positive SCA of 1 in the reciprocal cross.

Regarding LW, hybrid $\mathrm{P} 3 \times \mathrm{P} 8$ and $\mathrm{P} 2 \mathrm{xP} 9$ had the highest positive $\mathrm{SCA}(2.02)$ and 3.25 in the direct and reciprocal crosses, respectively. While hybrids $\mathrm{P} 1 \mathrm{xP} 8$ and $\mathrm{P} 4 \mathrm{xP} 6$ obtained the least positive SCA $(0.00)$ in the reciprocal; cross $\mathrm{P} 2 \mathrm{xP} 6$ in the direct cross also had the same SCA (0.00). Cross P3xP5 gave the highest negative SCA (-1.64) in the direct cross and cross P5xP7 with SCA of -1.27 in the reciprocal.

For FFW, SCA effect ranged from -0.09 to 0.89 in the direct cross and -0.01 to 0.86 for the reciprocal category. Whereas $\mathrm{P} 2 \mathrm{xP} 3$ had the highest positive SCA (0.89) in the direct cross, it recorded the highest negative SCA $(-1.23)$ in the reciprocal cross. Hybrid P1xP3 also recorded the highest negative SCA of -0.9 in the direct cross and the lowest negative SCA (0.01) in the reciprocal cross. 
Fresh LW, among the hybrids evaluated, ranged from-0.003-0.15 for both direct and reciprocal crosses. Hybrid $\mathrm{P} 3 \mathrm{xP} 8$ gave the highest positive SCA effect of 0.15 , and 0.19 in the direct and reciprocal crosses respectively. Hybrid P1XP7, P2XP6, P3XP4, P3XP6, P4XP5, P4XP8, P4XP9 from the direct cross and $\mathrm{P} 2 \times \mathrm{P} 6, \mathrm{P} 6 \times \mathrm{P} 8$ from the reciprocal gave the lowest positive SCA (0.00). Hybrid P1xP3 had the highest negative FLW of -0.09 in the direct cross while it gave the lowest negative FLW (-0.003)in the reciprocal cross (Table 3).

Heritability and genetic gain. High broad sense heritability was exhibited by all the traits,

TABLE 4. Heritability and genetic gain for the various gboma characters

\begin{tabular}{llrrc}
\hline Parameter & BH & PSD & SI (\%) & Genetic gain \\
\hline NLPP & 0.93 & 36.65 & 5 & 70.21 \\
& & & 10 & 59.82 \\
NB & 0.79 & 3.93 & 5 & 6.40 \\
& & & 10 & 5.45 \\
LL & 0.79 & 2.6 & 5 & 4.23 \\
& & & 10 & 3.61 \\
PH & 0.84 & 9.12 & 5 & 15.98 \\
& & & 10 & 13.44 \\
FL & 0.47 & 0.59 & 5 & 0.57 \\
& & & 10 & 0.49 \\
LW & 0.82 & 1.73 & 5 & 2.92 \\
& & & 10 & 2.49 \\
FFW & 0.60 & 1.33 & 5 & 1.64 \\
& & & 10 & 1.4 \\
FLW & 0.64 & 1.01 & 5 & 1.33 \\
& & & 10 & 1.13 \\
\hline
\end{tabular}

$\mathrm{BH}=$ Broad-Sense heritability, PSD $=$ Phenotypic standard deviation, $\mathrm{SI}=$ Selection intensity, NLLPP = Number of leaves per plant, $\mathrm{NB}=$ Number of branches per plant, $\mathrm{LL}=$ Leaf length, $\mathrm{PH}=$ Plant height, $\mathrm{FL}=$ Fruit length, LW = Leaf width, FFW = Fresh fruit width, FLW = Fresh leaf weight except FL (Table 4). LPP recorded the highest broad sense heritability. The average Broad sense heritability was 0.74 for all the traits. A high value of dominance ratio was observed for LW (Table 4).

The net genetic gain from selection intensity of 5 and $10 \%$ for the various yield components are presented in Table 4.

\section{DISCUSSION}

Combining ability effects. The main aim of this research was to determine the gene action governing the inheritance of yield components and combining ability in nine Gboma cultivars. This information would be useful in Gboma improvement programmes directed at improving fruit and leaf yield. The mean square values due to GCA was highly significant for most of the traits, indicating adequate amount of variability among the parental materials used for this study. Highly significant GCA and SCA effects for NLPP, FFW and PH (Table 1) implied that both additive and non-additive gene effects were important in determining the inheritance of these traits. This result is in concordance with those of Saha et al. (1991), Mohammed et al. (1995) and Al-Hubaity and Teli (2013).

Significant GCA for FL indicate the preponderance of additive gene action for this trait. In contrast, the inheritance of LW, NBPP, FLW were under the influence of non-additive gene action, because of their significant SCA effects. Results of the GCA/SCA ratio indicated that the relative contribution of additive to nonadditive effects varied widely from trait to trait. Where a ratio was closer or higher than unit indicates the predominance of additive gene action controlling that particular trait. The ratios indicated that GCA was higher than SCA for all the traits, except for number of branches and leave, indicating that most of the traits were largely controlled by additive gene action. Dudley and Moll (1969) reported that evaluation of combining ability of additive and non-additive gene performance within 
breeding population is important in determining the type of breeding methods that will successfully improve the performance of the studied characters.

Significant reciprocal effect for most of the traits (Table 1) indicate the contribution of cytoplasmic genetic effect to inheritance of those traits. For this reason, the choice of maternal parents is relevant in any breeding programme that focuses on Gboma for those important traits.

General combining ability. Estimates of GCA effect, revealed that CAGRIC 03 was the best combiner for number of branches, leaf length, plant height, fruit length and fresh leaf weight (Table 2); and thus contributed positive alleles in the crosses in which they were involved, while CAGRIC 01 exhibited the best combining abilities for number of leaves per plant and fruit width; and could therefore, be used to introgress such traits into promising lines. Low GCA estimate of plant height by CAGRIC 09 indicates that it was the most desirable combiner to reduce plant height and fruit length, indicating its usefulness for developing dwarf plants and shorter fruits. General combining ability has direct relationship with narrow sense heritability and represents fixable portion of genetic variation, therefore, helps in selection of parents suitable for hybridisation (Geletaand Labuschagne, 2006; Saleem et al., 2009) to develop cultivars with desired traits of interest (Gautam et al., 2016).

Specific combining ability. Most of the hybrids had positive SCA estimates (Table 3 ), suggesting that genes with some degree of dominance acted to reduce the expansion volume. Furthermore, positive SCA estimates were usually associated with crosses where at least one parent was a good combiner. Number LPP indicated that hybrid P4xP5 and P6xP8 showed a desirable specific combining ability for LPP in the direct and reciprocal crosses, respectively; while hybrid P3xP5 and
$\mathrm{P} 1 \mathrm{xP} 9$ showed an undesirable performance since they gave the highest negative SCA for leaves per plant. It was observed that hybrids $\mathrm{P} 3 \mathrm{xP} 4$ and $\mathrm{P} 5 \mathrm{xP} 7$ were the best combiners for greater NB in the direct and reciprocal crosses. It was evident that hybrid P1 xP3 was the desired hybrid for greater number of branches since it displayed exceptional specific combining ability in both direction. Additionally, a desirable specific combining ability was observed in $\mathrm{P} 1 \mathrm{xP} 8$ and $\mathrm{P} 2 \mathrm{xP} 9$ for leaf length in the direct and reciprocal direction, respectively. Contrary to the poor specific combining abilities exhibited by hybrids $\mathrm{P} 2 \mathrm{xP} 4$ and $\mathrm{P} 7 \mathrm{xP9}$ in the same direction.

The most promising hybrids for $\mathrm{PH}$ were P2xP8 and P2xP7 in the direct and reciprocal crosses, respectively (Table 3); since they showed a high specific combining ability for the trait. Hybrid P2xP4 showed an undesirable SCA for PH in the direct cross, implying that it was the most desirable combiner to reduce plant height; whereas hybrid P1xP9 replicated the same performance in the reciprocal. Although, hybrid $\mathrm{p} 6 \mathrm{xp} 8$ produced the highest SCA for FL in the direct crosses, hybrids $\mathrm{P} 1 \mathrm{xP} 8$ and $\mathrm{P} 3 \mathrm{xP} 7$ were the promising lines in the reciprocal direction. Hybrids $\mathrm{P} 1 \mathrm{xP} 3$, $\mathrm{P} 3 \times \mathrm{P} 4$, and $\mathrm{P} 6 \mathrm{xP} 8$ and $\mathrm{P} 5 \mathrm{xP} 8$ also showed undesirable SCA effect in the direct and reciprocal crosses, respectively.

For FL, hybrid P2x P3 was the superior (Table 3 ) and showed a promising SCA effect in the direct cross; yet it showed an undesirable SCA for FFW in the reciprocal cross. $\mathrm{P} 1 \mathrm{xP} 3$ was also undesirable due to its high negative SCA effect. Hybrid P2xP9 in the reciprocal set gave the highest SCA for FFW suggesting that it was the most promising in that category. Hybrid P3xP8 was the most desirable for high FLW since it had the highest SCA for both direct and reciprocal crosses. This underscores its usefulness in breeding programmes especially for FLW improvement. Conversely, hybrid $\mathrm{P} 1 \mathrm{xP} 3$ and $\mathrm{P} 2 \mathrm{xP} 3$ were the undesirable ones in the direct and reciprocal crosses, respectively. 
Heritability and genetic gain. High broad sense heritability estimates recorded for most of the traits indicate that the characters were least influenced by environment effects. Hence, selection for improvement of such characters may not be useful, because the broad sense heritability is based on the total genetic variance, which includes both fixable (additive) and non-fixable (dominance and epistatic) variances. However, high heritability accompanied with high genetic gain for LPP indicates that the heritability was due to additive gene effect, and selection may be effective for that character (Singh and Narayanan, 1993). High heritability for the other traits, accompanied with low genetic gain for the other traits, is indicative of non-additive gene effect. Nevertheless, the high heritability is being exhibited due to the favourable influence of the environment rather than the genotype and selection for such traits may not be rewarding. Moreover, low heritability estimate for FL, accompanied with low genetic gain, indicates that the character is highly influenced by environmental effects and selection would be ineffective. Estimation of heritability with genetic gain is very useful for predicting the gain under selection than solely heritability. The achievement of genetic gain is important for breeders after selecting for traits so that improved germplasm and new cultivars are released for further applied research, to satisfy the demand by farmers for high performing cultivars.

\section{CONCLUSION}

The study reveals a range of variations existing in the Gboma egg-plant yield traits. It is evident that inheritance of the various yield traits is controlled by both additive and non-additive gene effects. Furthermore, cytoplasmic or maternal gene effects play a major role in modifying the inheritance of the yield parameters. Hence, the choice of the maternal parent is relevant in any Gboma breeding programmes for fruit yield and leaves. High heritability estimates indicate that the traits are less influenced by the environment. The dominance of additive gene effects controlling a trait usually result into both high heritability and genetic gain, indicating effective selection for the trait; while those governed by nonadditive gene actions give high heritability with low genetic gain resulting in non-effective selection of the trait. CAGRIC 03 is a good combiner to increase number of branches, plant height, fruit length, leaf length and fresh leaf weight which makes it a valuable material for commercial utilisation.

\section{REFERENCES}

Agoreyo, B.O., Obansa, E.S. and Obanor, E.O. 2012. Comparative nutritional and phytochemical analyses of two varieties of Solanum melongena. Science World Journal 7(1): 5-8.

Al-Hamdani, H.U. Sh. 1999. Test the hybrid vigour and gene action in eggplant. M.Sc. Thesis. College of Agriculture and Forestry. Mosul Univ. Iraq. (In Arabic).

Al-Hayani, M.W.A. 2000. Full diallel crossing and determine genetic information for some important characters in eggplant. Ph.D. Thesis, College of Agriculture. University of Baghdad. (In Arabic)

Al-Hubaity, A.I. and Teli, J.A. 2013. Combining ability and heterosis in eggplant (Solanum melongena L.). Mesopotamia Journal of Agriculture 41(1):23-35.

Chandra, A., Verma, B.K and Sahpuke, R.H. 1990. Evaluated related chilli lines (Capsicum cinnumL). Vegetable Sciences 7: 47-48.

Dudley, J.W. and Moll, R.H. 1969. Interpretation and use of estimates of heritability and genetic variances in plant breeding. Crop Science 9(3): 257-262.

Falconer, D.S. 1989. Introduction to Quantitative Genetics. $3^{\text {rd }}$ Edition. John Wiley and Sons, New York. pp. 438.

Gautam, N., Kumar, M., Kumar, S., Amit Vikram, A., Dogra, R.K. and Bharat, N. 
2016. Combining ability analysis and gene action for yield and its contributing traits in tomato (Solanum lycopersicum L.) under North Western Himalayan region. Ecology, Environmental and Conservation 22 (1):345-349.

Geleta, L.F. and Labuschagne, M.T. 2006. Combining ability and heritability for vitamin $\mathrm{C}$ and total soluble solids in pepper (Capsicum annuum L.). Journal of the Science of Food and Agriculture 86(9):1317-1320.

Griffing, B. 1956. Concept of general and specific combining ability in relation to diallel crossing systems. Australian Journal of Biological Science 9:463-493.

Meteorological Service Department, Mampong Ashanti. 2007. Annual report. Sekyere west district of Ashanti Region, Ghana.

Nwodo, S.C., Abayomi, C.O., Eboji, O.K., Opeyemi, C.E., Olajumoke, A.K. and Damilola, I.D. 2011. Proximate and phytochemical analysis of Solanum aethiopicumL. and Solanum macrocarpon L. fruits. Research Journal of Chemical Sciences 1(3):436-439.

Nyadanu, D., Akromah, R., Adomako, B., Kwoseh, C., Lowor, S.T., Dzahini-Obiatey, H., Akrofi, A.Y. and Assuah, M.K. 2012. Inheritance and general combining ability studies of detached pod, leaf disc and natural field resistance to Phytophthora palmivora and Phytophthora megakarya in cacao (Theobroma cacao L.). Euphytica 188(2):253-264.

Nyadanu, D. and Lowor, S.T. 2015. Promoting competitiveness of neglected and underutilized crop species: Comparative analysis of nutritional composition of indigenous and exotic leafy and fruit vegetables in Ghana. Genetic Resources and Crop Evolution 62(1):131-140.

Oboh, G., Ekperigin, M.M. and Kazeem, M.I. 2005. Nutritional and haemolytic properties of eggplants (Solanum macrocarpon) leaves. Journal of Food Composition and Analysis 18(2):153-160.

PBTools, 2014. Biometrics and Breeding Informatics, PBGB Division, International Rice Research Institute, Los Baños, Laguna, Philippines.

Rao, D.S.R.M., Singh, H., Singh, B., Khola, O.P.S. and Faroda, A.S. 1990. Correlation and path coefficient analysis of seed yield and its components in sesame (Sesamum indicum L.). Haryana Agricultural University Journal of Research 20(4): 273276.

Robinson, H.F., Cornstock, R.E. and Harvey, P.H. 1949. Estimates of heritability and degree of dominance in corn. Agronomy Journal 41:353-359.

Saha, M.G., Hossain, A. K. M.A., Hoque, K. R. and Bhowmik, A. 1991. Genetic analysis of plant height and number of branches in brinjal (Solanum melongena L.) in Bangladesh. Annals of Bangladesh Agriculture (Bangladesh) 1(2):91-97.

Saleem, M.Y., Asghar, M., Haq, M.A., Rafique, T., Kamran, A. and Khan, A.A. 2009. Genetic analysis to identify suitable parents for hybrid seed production in tomato (Lycopersicon esculentum Mill.). Pakistan. Journal of Botany 41(3):1107-1116.

Schippers, R.R. 2000. African indigenous vegetables. An overview of the cultivated species. Natural Resources Institute/ACPEU Technical Centre for Agricultural and Rural Cooperation, Chatham, United Kingdom. 214pp.

Singh, P. and Narayanan, S.S. 1993. Biometrical Techniques in Plant Breeding. Kayani Publishers, New Delhi, India.

Singh, R.K. and Chaudhary, B.D. 1979. Biometrical methods in quantitative genetic analysis. Kayani Publishers, New Delhi, India. 